\title{
Management of COVID-19-Associated Acute Respiratory Failure with Alternatives to Invasive Mechanical Ventilation: High-Flow Oxygen, Continuous Positive Airway Pressure, and Noninvasive Ventilation
}

Barbara Bonnesen ${ }^{1}$, Jens-Ulrik Stæhr Jensen ${ }^{1,2} \mathbb{D}^{\mathbb{D}}$, Klaus Nielsen Jeschke ${ }^{3} \mathbb{D}^{\mathrm{D}}$, Alexander G. Mathioudakis ${ }^{4,5} \mathbb{D}^{\circ}$ Alexandru Corlateanu ${ }^{6}{ }^{D}$, Ejvind Frausing Hansen ${ }^{3}\left(\mathbb{D}\right.$, Ulla Møller Weinreich ${ }^{7,8}$, Ole Hilberg ${ }^{9,10}$ and Pradeesh Sivapalan $1, *$ (iD

1 Department of Medicine, Section of Respiratory Medicine, Herlev and Gentofte Hospital, University of Copenhagen, 2200 Copenhagen, Denmark; barbara.bertelsen@regionh.dk (B.B.); jens.ulrik.jensen@regionh.dk (J.-U.S.J.)

2 Department of Clinical Medicine, Faculty of Health Sciences, University of Copenhagen, 2200 Copenhagen, Denmark

3 Department of Respiratory Medicine, Copenhagen University Hospital-Hvidovre, 2650 Hvidovre, Denmark; klausnielsen.md@gmail.com (K.N.J.); ejvind.frausing.hansen@regionh.dk (E.F.H.)

check for updates

Citation: Bonnesen, B.; Jensen, J.-U.S.; Jeschke, K.N.; Mathioudakis, A.G.; Corlateanu, A.; Hansen, E.F.; Weinreich, U.M.; Hilberg, O.; Sivapalan, P. Management of COVID-19-Associated Acute Respiratory Failure with Alternatives to Invasive Mechanical Ventilation: High-Flow Oxygen, Continuous Positive Airway Pressure, and Noninvasive Ventilation. Diagnostics 2021, 11, 2259. https://doi.org/ $10.3390 /$ diagnostics11122259

Academic Editor: Fabiano Di Marco

Received: 3 November 2021

Accepted: 1 December 2021

Published: 2 December 2021

Publisher's Note: MDPI stays neutral with regard to jurisdictional claims in published maps and institutional affiliations.

Copyright: (C) 2021 by the authors. Licensee MDPI, Basel, Switzerland. This article is an open access article distributed under the terms and conditions of the Creative Commons Attribution (CC BY) license (https:/ / creativecommons.org/licenses/by/ $4.0 /)$.
4 Division of Infection, Immunity and Respiratory Medicine, School of Biological Sciences, The University of Manchester, Manchester Academic Health Science Centre, Manchester M23 9LT, UK; Alexander.Mathioudakis@Manchester.ac.uk

5 North West Lung Centre, Wythenshawe Hospital, Manchester University NHS Foundation Trust, Manchester M23 9LT, UK

6 Department of Respiratory Medicine, State University of Medicine and Pharmacy "Nicolae Testemitanu", 2004 Chisinau, Moldova; alexandru.corlateanu@usmf.md

7 Department of Respiratory Medicine, Aalborg University Hospital, University of Aalborg, 9100 Aalborg, Denmark; ulw@rn.dk

8 The Clinical Institute, Aalborg University, 9220 Aalborg, Denmark

9 Department of Medicine, Little Belt Hospital, 7100 Vejle, Denmark; ole.hilberg@rsyd.dk

10 Department of Regional Health Research, University of Southern Denmark, 5000 Odense, Denmark

* Correspondence: Pradeesh.s@dadlnet.dk; Tel.: +45-298-806-01

Abstract: Patients admitted to hospital with coronavirus disease 2019 (COVID-19) may develop acute respiratory failure (ARF) with compromised gas exchange. These patients require oxygen and possibly ventilatory support, which can be delivered via different devices. Initially, oxygen therapy will often be administered through a conventional binasal oxygen catheter or air-entrainment mask. However, when higher rates of oxygen flow are needed, patients are often stepped up to high-flow nasal cannula oxygen therapy (HFNC), continuous positive airway pressure (CPAP), bilevel positive airway pressure (BiPAP), or invasive mechanical ventilation (IMV). BiPAP, CPAP, and HFNC may be beneficial alternatives to IMV for COVID-19-associated ARF. Current evidence suggests that when nasal catheter oxygen therapy is insufficient for adequate oxygenation of patients with COVID-19associated ARF, CPAP should be provided for prolonged periods. Subsequent escalation to IMV may be implemented if necessary.

Keywords: COVID-19; acute respiratory failure; noninvasive ventilation; NIV; bilevel positive airway pressure; BiPAP; continuous positive airway pressure; CPAP; high-flow nasal cannula oxygen therapy; HFNC

\section{Introduction}

Patients infected with severe acute respiratory syndrome coronavirus 2 (SARS-CoV-2) may develop coronavirus disease 2019 (COVID-19) with viral pneumonia, acute respiratory failure $(A R F)$, or acute respiratory distress syndrome (ARDS) and may require hospital 
admission [1-3]. ARF is defined as the inability of the respiratory system to meet the oxygenation demands, ventilation, or metabolic requirements of the patient [4]. Treating patients with COVID-19 who have ARF involves oxygen supplementation and, in some cases, a degree of assisted ventilation. In the most severe cases of hypoxemia, invasive mechanical ventilation (IMV) may be necessary. However, access to IMV therapy may be limited, and this should be reserved for cases in which it is clearly indicated. IMV can result in complications linked to the intubation procedure and increased risks of ventilator-induced lung injury and ventilator-associated pneumonia, as well as long-term complications such as critical illness polyneuromyopathy [5-7]. Consequently, many intensive care units (ICUs) and nonintensive care medical departments looked for alternatives to IMV during the initial surge in COVID-19 cases. These alternatives included bilevel positive airway pressure (BiPAP), continuous positive airway pressure (CPAP), and high-flow nasal cannula oxygen therapy (HFNC). One substantial benefit of IMV is that it operates within a closed system, resulting in minimal spread of viral particles. Some clinicians were reluctant to use BiPAP, CPAP, and HFNC during the initial phase of the COVID-19 pandemic, due to the potential risk of transmission to healthcare staff [8-10]. The different types of ventilation treatment are associated with different risks of particle dispersion and disease transmission. Studies have shown that CPAP is not associated with significant leakage of exhaled air, whereas a single BiPAP circuit resulted in exhaled air reaching a distance up to $0.92 \mathrm{~m}$ from the BiPAP apparatus [11]. Similarly, a double BiPAP circuit was not associated with significant leakage. It may be relevant to compare the associated risks when ARF treatment efficacies are similar; however, as a German study stated, fear of transmission must not become the basis for selecting which ventilation method to use for patients [12]. Therefore, determining the best treatment options and alternative ventilation methods for patients with COVID-19 is critical. This review investigates the current treatment of patients with COVID-19 and ARF, as well as relevant ventilation strategies.

\section{Acute Respiratory Failure and COVID-19}

ARF can be categorized as type I or type II. Type I ARF is characterized by hypoxemia with a reduced partial pressure of oxygen in arterial blood $\left(\mathrm{PaO}_{2}\right)$. This is the type of respiratory failure most frequently observed in patients with COVID-19 who have had no prior respiratory illness or have had low levels of exposure to tobacco smoke [2]. Type II ARF is characterized by hypercapnia with an increased partial pressure of $\mathrm{CO}_{2}$ in arterial blood $\left(\mathrm{PaCO}_{2}\right.$ ) [13]. Patients with hypoxemic (type I) and hypercapnic (type II) ARF may benefit from different oxygenation strategies, to minimize the risk of deterioration and the requirement for IMV [14]. Evidence is accumulating that the course of hypoxemic lung injury in COVID-19 pneumonia may be more heterogeneous and may differ in various ways from the course of the disease in other pathogenic contexts [15,16]. In COVID-19 pneumonia, hypoxemic lung injury is accompanied by damage to the vascular endothelium and an increased risk of multiple organ failure. Therefore, COVID-19 pneumonia can be viewed as a systemic disease [12].

\section{Oxygenation Targets for Patients with COVID-19 and Respiratory Symptoms}

The HOT ICU trial, a randomized controlled trial (RCT) of 2928 patients, demonstrated that patients with ARF do not benefit from a target $\mathrm{PaO}_{2}$ of $60 \mathrm{~mm} \mathrm{Hg}$ in comparison to target $\mathrm{PaO}_{2}$ of $90 \mathrm{~mm} \mathrm{Hg}$ [17]. A smaller RCT found that in patients with ARDS but no exposure to SARS-CoV-2, liberal oxygen therapy (i.e., targeting peripheral oxygen saturation $\left(\mathrm{SpO}_{2}\right)$ of $\left.>96 \%\right)$ did not increase survival at 28 days, compared with conservative oxygen therapy (i.e., targeting $\mathrm{SpO}_{2}$ of $88-92 \%$ ) [18]. The British Thoracic Society recommends that oxygen should be prescribed to achieve a target saturation of $94-98 \%$ for most acutely ill patients, with a patient-specific target saturation of $88-92 \%$ for patients at risk of type II (hypercapnic) respiratory failure [19], and the Surviving Sepsis Campaign guidelines recommend a target $\mathrm{SpO}_{2}$ of 92-96\% [20]. However, oxygenation goals for patients with severe illness and respiratory symptoms should always depend intrinsically on underlying 
factors, and liberal oxygen treatment may increase the risk of mortality in patients with acute cerebral or coronary ischemia [21], as well as in those in ICUs [22].

The World Health Organization recommends a target $\mathrm{SpO}_{2}$ of $\geq 90 \%$ for nonpregnant ( $\geq 92-95 \%$ for pregnant) patients with COVID-19-associated ARF and also recommends reaching these targets by titration via a nasal cannula, simple face mask, or a face mask with a reservoir bag [23] (Figure 1). Studies on optimal target oxygenation in patients with COVID-19-associated ARF are scarce, and no RCTs have been performed to the best of our knowledge. An additional challenge on this subject is the traditional mode of prescribing oxygen therapy, which is often not documented or specified to the degree, which is common with pharmaceutical therapies [24]. Patients with COVID-19-associated ARF, despite the provision of maximal oxygen levels via a face mask, should be promptly identified and evaluated with a view to providing respiratory support via HFNC, CPAP, or intubation and mechanical ventilation [25] (Figure 1).

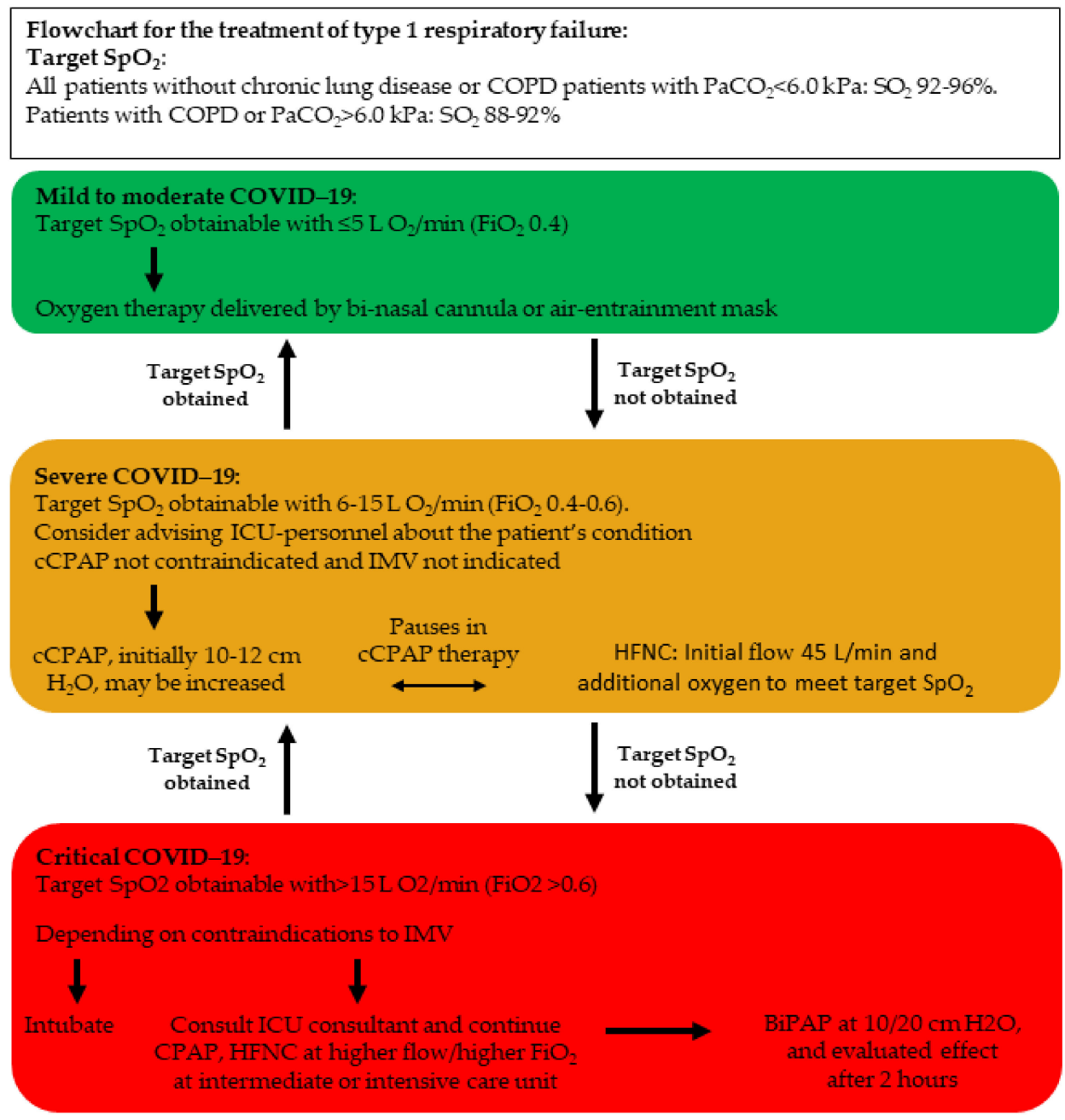

Figure 1. Flowchart for the treatment of type 1 respiratory failure. $\mathrm{SpO}_{2}=$ peripheral oxygen saturation, $\mathrm{FiO}_{2}=$ fraction of inspired oxygen, $\mathrm{PaCO}_{2}=$ partial pressure of carbon dioxide in arterial blood, $\mathrm{CCPAP}=$ continuous (i.e., nonintermittent) continuous positive airway pressure, $\mathrm{HFNC}=$ highflow nasal cannula oxygen therapy, IMV = invasive mechanical ventilation, $\mathrm{BiPAP}=$ bilevel positive airway pressure, $\mathrm{COPD}=$ chronic obstructive pulmonary disease, $\mathrm{COVID}-19=$ coronavirus disease 2019. Adapted from Nielsen Jeschke K. et al. 2020 [25]. 


\section{Diagnosing Acute Respiratory Failure}

In hypoxemic (type I) respiratory failure patients are diagnosed by a peripheral saturation measurement or preferably an arterial gas analysis. Hypoxemic respiratory failure is defined as a lowered $\mathrm{PaO}_{2}$ or $\mathrm{SpO}_{2}$ measurement (hypoxemia) with either a standard (normocapnia) or low (hypocapnia) $\mathrm{PaCO}_{2}$ measurement. For a certain diagnosis of respiratory failure, $\mathrm{PaO}_{2}<60 \mathrm{mmHg}$ by arterial gas analysis is mandatory.

In patients with COVID-19-associated ARF, the $\mathrm{PaO}_{2} / \mathrm{FiO}_{2}$ ratio was able to predict severity in a cohort of 421 patients [26], as well as in a smaller cohort of 150 patients. In the latter cohort, the authors were able to calculate an optimal cut-off $\mathrm{PaO}_{2} / \mathrm{FiO}_{2}$ ratio of $274 \mathrm{mmHg}$, which could distinguish between patients with mild disease and patients with severe disease with a sensitivity of $72 \%$ and specificity $85 \%$ [27], and it also contributed to a predictive composite score along with age, platelets, $\mathrm{pH}$, blood urea nitrogen, temperature, $\mathrm{PaCO}_{2}$, and Glasgow Coma Scale in a cohort of 937 patients [28].

A study has examined an algorithm for predicting COVID-19-associated ARDS among 964 patients who would develop ARDS within $12 \mathrm{~h}$, as compared to 4712 patients who did not. The machine algorithm found that the two most important predictive factors for the development of COVID-associated ARDS were saturation in the shape of the lowest measured $\mathrm{SpO}_{2}$ and standard deviation of measured $\mathrm{SpO}_{2}$. This was complemented by age, maximal $\mathrm{FiO}_{2}$, maximal respiratory rate, and maximal and standard deviation $\mathrm{O}_{2}$ flow. Hence, and perhaps not surprising, several different respiratory measures seem to contribute substantially to predicting ARDS in patients with COVID-19. However, as a possible future biomarker, the lowest measured platelet count also contributed to the algorithm [29]

In patients without COVID-19, several biomarkers seem promising in diagnosing and predicting the development of $\mathrm{ARF}$, and some have already to some degree proven their value. Plasma surfactant protein D (SP-D) has been shown to increase within $48 \mathrm{~h}$ of admission to ICU in patients who developed ARDS and to predict the long-term need for IMV and mortality [30-32], and angiopoietin-2 was able to predict pulmonary affection in cohort studies in critically ill patients with various underlying courses [33-36] and also predict severity of illness and mortality [37-40].

Among patients with COVID-19, a cohort study of 259 patients found that SOFA score and ROX index predicted HFNC failure to IMV [41], and in a small cohort, male sex, obesity, African American ethnicity, comorbidities, and prior immunosuppression predicted HFNC failure and need for IMV [42], though in this small study, no biomarker was able to predict a respiratory worsening [42]. A retrospective cohort study of 610 patients showed a compound of age, history of coronary heart disease, CRP, aspartate aminotransferase, D-dimer, and neutrophil-to-lymphocyte ratio was able to form an acceptable ROC curve [43], and in a retrospective cohort study of 638 patients, CRP, neutrophil-to-lymphocyte ratio, and D-dimer were associated with adverse events, such as acute myocardial injury, respiratory failure, acute kidney injury, mechanical ventilation, intensive care unit admission, multiple organ dysfunction syndromes, and death [44].

Elevated levels of LDH have also been associated with severity [45,46], and in a cohort study of 100 patients, ferritin was able to predict in-hospital mortality with a superior ROC curve to CRP [47], and in a cohort of 153 patients, severity of disease was associated with plasma levels of interleukin-6 (IL-6), CRP, soluble-IL2 receptor (IL2R $\alpha$ ), procalcitonin (PCT), and ferritin [48]. IL-6 has also been shown to correlate to $\mathrm{SpO}_{2}$ and $\mathrm{PaO}_{2}$ in 48 patients, and it correlated well with CRP in these patients [49]. This is not in contrast to studies on patients with ARF without COVID-19; however, in this context, IL-6 was a somewhat inconsistent predictor of ARF, ARDS, severity, and mortality [37,38,50-52]. Similarly, PCT has in patients without COVID-19 been a poor indicator for need for antibiotic treatment [53]. 


\section{Continuous Positive Airway Pressure}

CPAP is a positive airway pressure therapy that delivers a set pressure of airflow to the airways. The $\mathrm{C}$ for continuous in CPAP refers to the constant pressure, which is maintained throughout the respiratory cycle, both when the person is breathing in (inspiration) and breathing out (expiration). This therapy can be administered for prolonged periods of time, referred to as continuously administered CPAP (CCPAP), or for very short time intervals, referred to as intermittently administered CPAP. In this review, we only discuss cCPAP therapy.

A CPAP device consists of a unit that generates airflow, which is delivered to the airway through either a helmet or face mask, and the effects of CPAP have been studied in more than 1100 patients with ARF due to COVID-19 pneumonia [3]. Continuous therapy with CPAP for COVID-19-associated ARF may be considered when a patient with hypoxic respiratory failure requires $6-15 \mathrm{~L} / \mathrm{min}$ oxygen (i.e., fraction of inspired oxygen $\left.\left(\mathrm{FiO}_{2}\right), 0.4-0.6\right)$ to achieve an acceptable level of oxygen saturation, and clinicians agree that escalation to IMV would be an option, but it is not immediately necessary (Figure 1). When commencing the CPAP therapy, an initial pressure of $10-12 \mathrm{~cm} \mathrm{H}_{2} \mathrm{O}$ may be applied, because positive end-expiratory pressure should be high, as in other cases of severe ARF $[25,54,55]$. Usually, CPAP therapy has an almost instantaneous effect on improving the condition of patients with COVID-19-associated ARF; however, if more oxygen is necessary, then intubation and IMV may be required [25].

The RECOVERY-RS trial, led by the University of Warwick and Queen's University Belfast, is the world's largest noninvasive respiratory support trial for COVID-19, with over 1200 participants taking place across 48 United Kingdom hospitals. This multicenter adaptive RCT compared the use of CPAP (oxygen and positive pressure delivered via a tightly fitting mask), HFNC, and standard care (standard oxygen therapy). The results showed that treating hospitalized COVID-19 patients who had ARF with continuous CPAP reduced the need for IMV [56]. In the CPAP group, 137 of 377 participants (36.3\%) either needed mechanical ventilation or died within 30 days, compared with 158 of 356 participants $(44.4 \%)$ in the conventional oxygen therapy group (unadjusted odds ratio, $0.72 ; 95 \%$ confidence interval (CI), 0.53 to $0.96 ; p=0.03$ ). However, there was a small increase in the number of serious adverse events with CPAP compared with conventional oxygen therapy [56]. On the other hand, one small RCT and several cohort studies have shown that continuous CPAP therapy is not successful for all patients, and failure rates are higher when the treatment ceiling excludes IMV, such as when treating elderly patients who have many comorbidities [55,57-62]. Continuous CPAP has particularly beneficial effects on respiratory rate and oxygenation levels, and the majority of patients with COVID-19 who are offered continuous CPAP therapy (83-97\%) are able to tolerate the treatment $[57,63]$. CPAP weaning may be undertaken reasonably safely $(83 \%$ success rate) after treatment has successfully improved respiratory performance and the modified ROX index $\left(\mathrm{PaO}_{2} / \mathrm{FiO}_{2} /\right.$ respiratory rate) has increased to $8.4 \mathrm{~mm} \mathrm{Hg} / \mathrm{bpm}$ [62]. Initial 6-month follow-up studies of survivors of COVID-19-associated ARF treated with continuous CPAP were optimistic concerning respiratory parameters and exercise capacity [64].

\section{Bilevel Positive Airway Pressure}

BiPAP ventilates by applying positive pressure into the lungs through a mask or a helmet [38]. BiPAP can be used as initial treatment, followed by a step up to IMV if needed, or as a method for weaning patients off IMV. BiPAP is very effective, and many guidelines describe BiPAP as the first-line treatment for ARF caused by acute exacerbations of chronic obstructive pulmonary disease or acute cardiogenic pulmonary edema $[65,66]$. One study investigated the efficacy of BiPAP in treating ARF resulting from various etiologies [67]. The highest BiPAP failure rate was among patients with hypoxemic respiratory failure, and the lowest was among patients with acute pulmonary edema [41]. Previous studies have shown that BiPAP can effectively treat viral pneumonia with hypoxic respiratory failure. Failure rates were as low as approximately $30 \%$. For influenza A (H1N1), the failure rate 
was $13-77 \%$ [66]. Potential difficulties associated with BiPAP treatment include low patient compliance, claustrophobia, dyspnea, and development of skin rashes $[6,68]$.

BiPAP may be used to treat COVID-19-associated ARF at an initial inspiratory pressure of $20 \mathrm{~cm} \mathrm{H}_{2} \mathrm{O}$ and an expiratory pressure of $10 \mathrm{~cm} \mathrm{H}_{2} \mathrm{O}$ combined with low tidal volumes such as $4-8 \mathrm{~mL} / \mathrm{kg}[25,54]$. The HENIVOT trial, a multicenter RCT of 110 patients (median age, 65 years), evaluated whether helmet BiPAP for two days followed by HFNC therapy was superior to HFNC alone. Though the primary outcome was not met, among the secondary outcomes, the rate of endotracheal intubation was significantly lower in the BiPAP group than in the HFNC group ( $30 \%$ vs. $51 \% ; p=0.03$ ). These data are obviously not conclusive, and the area needs further investigation [69]. As with CPAP treatment, age, comorbidities, and the severity of the disease predicted BiPAP treatment failure and mortality in patients with COVID-19-associated ARF [70,71]. Treating patients who are in the prone position with BiPAP has produced promising results; however, the relevant data are limited because few patients are initially treated in the prone position [72,73]. Overall, BiPAP failure rates ranged from 48 to 53\% [70,71]. Finally, BiPAP has been used as a step-down measure from IMV, with BiPAP being implemented immediately after early extubation in patients with severe COVID-19-associated ARF. This strategy reduced the duration of intubation, the extubation failure rate, and the need for reintubation. However, patients treated with BiPAP had also been given more antiviral agents and more corticosteroids. Larger studies are needed to verify the few preliminary data on these BiPAP strategies. Both CPAP and BiPAP treatment are associated with a considerable risk of complications such as pneumothorax/pneumomediastinum, hemodynamic instability, and delirium and require careful monitoring $[56,57,74]$. These risks may be increased among patients suffering from COVID-19-associated ARF [75].

\section{High-Flow Nasal Cannula Oxygen Therapy}

HFNC involves the delivery of a high flow of warm humidified oxygen (up to $60 \mathrm{~L} / \mathrm{min}$ ) through a small nasal cannula, improving oxygenation and reducing respiratory rates, as well as providing higher concentrations of oxygen than therapy with supplemental oxygen alone [76,77]. In patients who did not have COVID-19, the European Respiratory Society (ERS) recommends HFNC therapy to patients with hypoxic respiratory failure over conventional nasal cannula therapy and NIV; however, they do not recommend HFNC over NIV in patients at high risk of extubation failure, in patients with chronic obstructive pulmonary disease (COPD), or in patients with hypercapnic ARF [78]. Treatment with HFNC resulted in similar mortality rates but less frequent intubation, compared to patients treated with conventional oxygen therapy [79], and HFNC is usually tolerated quite well [80].

Preliminary data from a recent RCT involving HFNC treatment of COVID-19 patients with ARF $(n=1272)$ suggested that routine use of HFNC did not improve patient outcomes, compared with conventional oxygen therapy. The RCT did not find any benefits associated with using HFNC rather than conventional oxygen therapy. A total of 184 of 414 participants who received HFNC (44.4\%) vs. 166 of 368 participants who received conventional oxygen therapy $(45.1 \%)$ met the composite endpoint of tracheal intubation or death within 30 days (unadjusted odds ratio, $0.97 ; 95 \% \mathrm{CI}, 0.73$ to $1.29 ; p=0.85$ ), whereas continuous CPAP was superior to conventional oxygen therapy [56]. Therefore, routinely offering HFNC as the main form of respiratory support for patients with respiratory failure due to COVID-19 is not recommended [81], but HFNC may be suitable for patients who need a break from CPAP (e.g., at mealtimes) or for patients who are being weaned off CPAP or need humidified oxygen or for patients who cannot tolerate CPAP. As described above, evidence from the HENIVOT trial [69] suggests that for COVID-19 patients with moderate-to-severe hypoxemia, treatment with helmet noninvasive ventilation did not increase the number of days free of respiratory support within 28 days, compared with high-flow nasal oxygen (mean difference, 2 days; $95 \% \mathrm{CI},-2$ to $6 ; p=0.26$ ). In addition, helmet noninvasive ventilation followed by HFNC significantly reduced the number of 
patients who needed invasive ventilation, compared with HFNC alone. Previous small national studies on clinical outcomes in patients with COVID-19 who were treated with HFNC were mostly uncontrolled and retrospective and did not reach definitive conclusions [82-84]. This may be partly due to confounding variables and biases, as well as the difficulties associated with extrapolating results from one population to another. In addition, some of these studies primarily had exploratory relevance in the earlier stages of the SARS-CoV-2 pandemic. Looking at the use of HFNC from another point of view, a retrospective study of patients with COVID-19 who developed ARF found that $41 \%$ of those treated with HFNC experienced treatment failure and required BiPAP or intubation. The HFNC treatment failure rate was highest among patients with low $\mathrm{PaO}_{2} / \mathrm{FiO}_{2}$ ratios. This marker is frequently used in intensive care settings and may help to identify those patients with COVID-19 and ARF who are most likely to require escalation in therapy from HFNC [85]. Further research is needed to clarify particular aspects of HFNC, including treatment targets, safety, efficacy, and how it should be administered to patients with ARF and COVID-19.

\section{Prone Positioning}

Positioning as a therapy method in non-ICU patients with COVID-19-associated ARF has also been examined to better oxygenate and avoid IMV. So far, studies on positioning in non-ICU patients have been conducted with prone positioning undertaken only during waken periods. Two small RCTs have been conducted so far. An RCT feasibility study of 60 patients with hypoxic ARF secondary to COVID-19 pneumonia found no effect of prone position on the need for additional respiratory therapy or mortality; however, only 13 patients encouraged to lay in the prone position were able to self-prone for at least 6 $\mathrm{h}$ a day. In the standard care group, 16 patients chose by themselves to spend time in the prone position, which may have masked an effect [86]. A pilot trial designed as a cluster study in a quaternary care center included five inpatient medical service teams to either encourage prone positioning or standard care with no randomization of patients found no effect on oxygen saturation to fraction of inspired oxygen ratio of encouragement of medical service teams to prone positioning [87]. Finally, a small cohort study of 20 patients examined peripheral oxygen saturation and showed an improvement from $96 \%$ in the supine position to $98 \%$ in the prone position $(p=0.008)$. However, the patients reported worsening in comfort score [88]. Hence, any effect of prone positioning in non-ICU patients remains to be shown but can also not be rejected with the currently available evidence.

\section{Stepping up the Therapeutic Regimens}

A retrospective observational study [89] investigated moderate-to-severe ARDS associated with COVID-19 and studied a treatment regimen in which supplemental oxygen was provided, followed by BiPAP/CPAP if oxygen saturation levels and respiratory rates did not improve. This was followed by IMV if signs of BiPAP failure were observed, such as worsening of dyspnea or hypoxemia, respiratory acidosis, or circulatory shock. The authors found that BiPAP was associated with a lower association with IMW therapy. Two studies showed a benefit of a stepwise approach. The recommended approach begins with HFNC as the first-line treatment. If oxygen saturation levels decrease and respiratory rates increase to $>30 / \mathrm{min}$, treatment should be escalated to BiPAP or CPAP. Subsequently, intubation is indicated if parameters that are used to monitor the patient's condition worsen. These two papers suggest a strategy in which HFNC, BiPAP, and IMV are all involved at different stages of ARF depending on the status of the patient [12,89].

\section{Conclusions}

BiPAP, CPAP, and HFNC may be beneficial alternatives to IMV for COVID-19-associated ARF. One large, comprehensive RCT [56] has shown that continuous CPAP is superior to conventional oxygen therapy delivered by binasal cannula; however, HFNC did not prove superior to oxygen therapy by binasal cannula. Thus, continuous CPAP should be preferred 
for patients with COVID-19-associated ARF if nasal catheter oxygen therapy is insufficient for adequate oxygenation, and IMV is not indicated. HFNC therapy can be used if CPAP is not tolerated. For patients with COVID-19-associated ARF, a stepwise treatment approach that is based on patient status and includes several consecutive ventilation strategies may be the way forward.

Author Contributions: The contributions of the authors of this review are as follows: Conceptualization, P.S.; methodology, P.S., B.B. and J.-U.S.J.; software, P.S. and J.-U.S.J.; validation, P.S., B.B. and J.-U.S.J.; formal analysis, P.S. and B.B.; investigation, P.S. and B.B.; resources, P.S. and J.-U.S.J.; data curation, P.S. and J.-U.S.J.; writing the original draft of the review, P.S., J.-U.S.J. and B.B.; reviewing and editing the draft, P.S., B.B., K.N.J., A.G.M., A.C., E.F.H., U.M.W., O.H. and J.-U.S.J.; visualization, P.S.; supervision, J.-U.S.J.; project administration, P.S.; funding acquisition, P.S. and J.-U.S.J. All authors have read and agreed to the published version of the manuscript.

Funding: The research salary of P.S. was sponsored by Herlev and Gentofte Hospital, University of Copenhagen. J.-U.S.J. is sponsored by a grant from the Novo-Nordisk Foundation, Grant No. NNF20SA0062834.

Acknowledgments: This work was supported by the COP:TRIN network www.coptrin.dk.

Conflicts of Interest: All authors have completed the ICMJE uniform disclosure form, describing any conflicts of interest. None of the authors have any conflicts of interest that are directly related to this work.

\section{References}

1. Agarwal, S.K.; Heiss, G.; Barr, R.G.; Chang, P.P.; Loehr, L.R.; Chambless, L.E.; Shahar, E.; Kitzman, D.W.; Rosamond, W.D. Airflow obstruction, lung function, and risk of incident heart failure: The Atherosclerosis Risk in Communities (ARIC) study. Eur. J. Heart Fail. 2012, 14, 414-422. [CrossRef] [PubMed]

2. Lentz, S.; Roginski, M.A.; Montrief, T.; Ramzy, M.; Gottlieb, M.; Long, B. Initial emergency department mechanical ventilation strategies for COVID-19 hypoxemic respiratory failure and ARDS. Am. J. Emerg. Med. 2020, 38, 2194-2202. [CrossRef] [PubMed]

3. Chalmers, J.D.; Crichton, M.L.; Goeminne, P.C.; Cao, B.; Humbert, M.; Shteinberg, M.; Antoniou, K.M.; Ulrik, C.S.; Parks, H.; Wang, C.; et al. Management of hospitalised adults with coronavirus disease 2019 (COVID-19): A European Respiratory Society living guideline. Eur. Respir. J. 2021, 57, 2100048. [CrossRef] [PubMed]

4. Parrillo, J.D.R. Critical Care Medicine, 3rd ed.; Mosby Elsevier: Maryland, MO, USA, 2007.

5. Putowski, Z.; Czok, M.; Liberski, P.S.; Krzych, Ł.J. Basics of mechanical ventilation for non-aneasthetists Part 2: Clinical aspects. Adv. Respir. Med. 2020, 88, 580-589. [CrossRef]

6. Demoule, A.; Brochard, L.; Dres, M.; Heunks, L.; Jubran, A.; Laghi, F.; Mekontso-Dessap, A.; Nava, S.; Ouanes-Besbes, L.; Peñuelas, O.; et al. How to ventilate obstructive and asthmatic patients. Intensive Care Med. 2020, 46, 2436-2449. [CrossRef]

7. McClafferty, B.; Umer, I.; Fye, G.; Kepko, D.; Kalayanamitra, R.; Shahid, Z.; Ramgobin, D.; Cai, A.; Groff, A.; Bhandari, A.; et al. Approach to critical illness myopathy and polyneuropathy in the older SARS-CoV-2 patients. J. Clin. Neurosci. 2020, 79, 241-245. [CrossRef]

8. Raoof, S.; Nava, S.; Carpati, C. High-Flow, Noninvasive Ventilation and Awake (Nonintubation) Proning in Patients With Coronavirus Disease 2019 With Respiratory Failure. Chest 2020, 158, 1992-2002. [CrossRef]

9. Cheung, J.C.H.; Ho, L.T.; Cheng, J.V.; Cham, E.Y.K.; Lam, K.N. Staff safety during emergency airway management for COVID-19 in Hong Kong. Lancet Respir. Med. 2020, 8, e19. [CrossRef]

10. Wax, R.S.; Christian, M.D. Practical recommendations for critical care and anesthesiology teams caring for novel coronavirus (2019-nCoV) patients. Can. J. Anaesth. 2020, 67, 568-576. [CrossRef]

11. Winck, J.C.; Ambrosino, N. COVID-19 pandemic and non invasive respiratory management: Every Goliath needs a David. An evidence based evaluation of problems. Pulmonology 2020, 26, 213-220. [CrossRef]

12. Windisch, W.; Weber-Carstens, S.; Kluge, S.; Rossaint, R.; Welte, T.; Karagiannidis, C. Invasive and Non-Invasive Ventilation in Patients With COVID-19. Dtsch. Arztebl. Int. 2020, 117, 528-533. [CrossRef]

13. Shebl, E.; Burns, B. Respiratory Failure; StatPearls: Treasure Island, FL, USA, 2021.

14. Tan, D.; Walline, J.H.; Ling, B.; Xu, Y.; Sun, J.; Wang, B.; Shan, X.; Wang, Y.; Cao, P.; Zhu, Q.; et al. High-flow nasal cannula oxygen therapy versus non-invasive ventilation for chronic obstructive pulmonary disease patients after extubation: A multicenter, randomized controlled trial. Crit. Care 2020, 24, 489. [CrossRef]

15. Balbi, M.; Conti, C.; Imeri, G.; Caroli, A.; Surace, A.; Corsi, A.; Mercanzin, E.; Arrigoni, A.; Villa, G.; Di Marco, F.; et al. Post-discharge chest CT findings and pulmonary function tests in severe COVID-19 patients. Eur. J. Radiol. 2021, 138, 109676. [CrossRef]

16. Ojha, V.; Mani, A.; Pandey, N.N.; Sharma, S.; Kumar, S. CT in coronavirus disease 2019 (COVID-19): A systematic review of chest CT findings in 4410 adult patients. Eur. Radiol. 2020, 30, 6129-6138. [CrossRef] 
17. Schjørring, O.L.; Klitgaard, T.L.; Perner, A.; Wetterslev, J.; Lange, T.; Siegemund, M.; Bäcklund, M.; Keus, F.; Laake, J.H.; Morgan, M.; et al. Lower or Higher Oxygenation Targets for Acute Hypoxemic Respiratory Failure. N. Engl. J. Med. 2021, 384, $1301-1311$. [CrossRef]

18. Barrot, L.; Asfar, P.; Mauny, F.; Winiszewski, H.; Montini, F.; Badie, J.; Quenot, J.P.; Pili-Floury, S.; Bouhemad, B.; Louis, G.; et al. Liberal or Conservative Oxygen Therapy for Acute Respiratory Distress Syndrome. N. Engl. J. Med. 2020, 382, 999-1008. [CrossRef]

19. O'driscoll, B.R.; Howard, L.S.; Earis, J.; Mak, V. BTS guideline for oxygen use in adults in healthcare and emergency settings. Thorax 2017, 72 (Suppl. S1), ii1-ii90. [CrossRef]

20. Rhodes, A.; Evans, L.E.; Alhazzani, W.; Levy, M.M.; Antonelli, M.; Ferrer, R.; Kumar, A.; Sevransky, J.E.; Sprung, C.L.; Nunnally, M.E.; et al. Surviving Sepsis Campaign: International Guidelines for Management of Sepsis and Septic Shock: 2016. Intensive Care Med. 2017, 43, 304-377. [CrossRef]

21. Chu, D.K.; Kim, L.H.; Young, P.J.; Zamiri, N.; Almenawer, S.A.; Jaeschke, R.; Szczeklik, W.; Schünemann, H.J.; Neary, J.D.; Alhazzani, W. Mortality and morbidity in acutely ill adults treated with liberal versus conservative oxygen therapy (IOTA): A systematic review and meta-analysis. Lancet 2018, 391, 1693-1705. [CrossRef]

22. Girardis, M.; Busani, S.; Damiani, E.; Donati, A.; Rinaldi, L.; Marudi, A.; Morelli, A.; Antonelli, M.; Singer, M. Effect of Conservative vs Conventional Oxygen Therapy on Mortality Among Patients in an Intensive Care Unit: The Oxygen-ICU Randomized Clinical Trial. JAMA 2016, 316, 1583-1589. [CrossRef]

23. World Health Organization. Clinical Management of Severe Acute Respiratory Infection When Novel Coronavirus (nCoV) Infection Is Suspected. 2020. Available online: https://www.who.int/publications-detail/clinical-management-of-severeacuterespiratory-infection-when-novel-coronavirus-(ncov)-infection-is-suspected (accessed on 12 February 2021).

24. Barrett, R.; Catangui, E.; Scott, R. Acute oxygen therapy: A cross-sectional study of prescribing practices at an English hospital immediately before COVID-19 pandemic. Expert Rev. Respir. Med. 2021, 15, 277-284. [CrossRef] [PubMed]

25. Nielsen Jeschke, K.; Bonnesen, B.; Hansen, E.F.; Jensen, J.U.S.; Lapperre, T.S.; Weinreich, U.M.; Hilberg, O. Guideline for the management of COVID-19 patients during hospital admission in a non-intensive care setting. Eur. Clin. Respir. J. 2020, 7, 1761677. [CrossRef] [PubMed]

26. Gündogan, K.; Akbudak, I.H.; Hanci, P.; Halacli, B.; Temel, S.; Güllü, Z.; Inci, K.; Bilir, Y.; Bozkurt, F.T.; Yildirim, F.; et al. Clinical Outcomes and Independent Risk Factors for 90-Day Mortality in Critically Ill Patients with Respiratory Failure Infected with SARS-CoV-2: A Multicenter Study in Turkish Intensive Care Units. Balk. Med. J. 2021, 38, 296-303. [CrossRef] [PubMed]

27. Sinatti, G.; Santini, S.J.; Tarantino, G.; Picchi, G.; Cosimini, B.; Ranfone, F.; Casano, N.; Zingaropoli, M.A.; Iapadre, N.; Bianconi, S.; et al. $\mathrm{PaO}_{2} / \mathrm{FiO}_{2}$ ratio forecasts COVID-19 patients' outcome regardless of age: A cross-sectional, monocentric study. Intern. Emerg. Med. 2021, 1-9. [CrossRef]

28. Plečko, D.; Bennett, N.; Mårtensson, J.; Dam, T.A.; Entjes, R.; Rettig, T.C.; Dongelmans, D.A.; Boelens, A.D.; Rigter, S.; Hendriks, S.H.; et al. Rapid Evaluation of Coronavirus Illness Severity (RECOILS) in intensive care: Development and validation of a prognostic tool for in-hospital mortality. Acta Anaesthesiol. Scand. 2021. [CrossRef]

29. Singhal, L.; Garg, Y.; Yang, P.; Tabaie, A.; Wong, A.I.; Mohammed, A.; Chinthala, L.; Kadaria, D.; Sodhi, A.; Holder, A.L.; et al. eARDS: A multi-center validation of an interpretable machine learning algorithm of early onset Acute Respiratory Distress Syndrome (ARDS) among critically ill adults with COVID-19. PLoS ONE 2021, 16, e0257056. [CrossRef]

30. Eisner, M.D.; Parsons, P.; Matthay, M.A.; Ware, L.; Greene, K. Plasma surfactant protein levels and clinical outcomes in patients with acute lung injury. Thorax 2003, 58, 983-988. [CrossRef]

31. Determann, R.M.; Royakkers, A.A.; Haitsma, J.J.; Zhang, H.; Slutsky, A.S.; Ranieri, V.M.; Schultz, M.J. Plasma levels of surfactant protein D and KL-6 for evaluation of lung injury in critically ill mechanically ventilated patients. BMC Pulm. Med. 2010, 10,6. [CrossRef]

32. Ware, L.B.; Koyama, T.; Billheimer, D.D.; Wu, W.; Bernard, G.R.; Thompson, B.T.; Brower, R.G.; Standiford, T.J.; Martin, T.R.; Matthay, M.A.; et al. Prognostic and pathogenetic value of combining clinical and biochemical indices in patients with acute lung injury. Chest 2010, 137, 288-296. [CrossRef]

33. Agrawal, A.; Matthay, M.A.; Kangelaris, K.N.; Stein, J.; Chu, J.C.; Imp, B.M.; Cortez, A.; Abbott, J.; Liu, K.D.; Calfee, C.S. Plasma angiopoietin-2 predicts the onset of acute lung injury in critically ill patients. Am. J. Respir. Crit. Care Med. 2013, 187, 736-742. [CrossRef]

34. Ware, L.B.; Zhao, Z.; Koyama, T.; Brown, R.M.; Semler, M.W.; Janz, D.R.; May, A.K.; Fremont, R.D.; Matthay, M.A.; Cohen, M.J.; et al. Derivation and validation of a two-biomarker panel for diagnosis of ARDS in patients with severe traumatic injuries. Trauma Surg. Acute Care Open 2017, 2, e000121. [CrossRef]

35. Uchida, T.; Ito, H.; Yamamoto, H.; Ohno, N.; Asahara, M.; Yamada, Y.; Yamaguchi, O.; Tomita, M.; Makita, K. Elevated levels of angiopoietin-2 as a biomarker for respiratory failure after cardiac surgery. J. Cardiothorac. Vasc. Anesth. 2014, 28, $1293-1301$. [CrossRef]

36. Van der Heijden, M.; Pickkers, P.; van Nieuw Amerongen, G.P.; van Hinsbergh, V.W.; Bouw, M.P.; van der Hoeven, J.G.; Groeneveld, A.J. Circulating angiopoietin-2 levels in the course of septic shock: Relation with fluid balance, pulmonary dysfunction and mortality. Intensive Care Med. 2009, 35, 1567-1574. [CrossRef] 
37. Hoeboer, S.H.; Groeneveld, A.J.; der Heijden, M.V.; Oudemans-van Straaten, H.M. Serial inflammatory biomarkers of the severity, course and outcome of late onset acute respiratory distress syndrome in critically ill patients with or at risk for the syndrome after new-onset fever. Biomark. Med. 2015, 9, 605-616. [CrossRef]

38. Bime, C.; Casanova, N.; Oita, R.C.; Ndukum, J.; Lynn, H.; Camp, S.M.; Lussier, Y.; Abraham, I.; Carter, D.; Miller, E.J.; et al. Development of a biomarker mortality risk model in acute respiratory distress syndrome. Crit. Care 2019, 23, 410. [CrossRef]

39. Gallagher, D.C.; Parikh, S.M.; Balonov, K.; Miller, A.; Gautam, S.; Talmor, D.; Sukhatme, V.P. Circulating angiopoietin 2 correlates with mortality in a surgical population with acute lung injury/adult respiratory distress syndrome. Shock 2008, $29,656-661$. [CrossRef]

40. Ma, S.; Zhao, M.L.; Wang, K.; Yue, Y.F.; Sun, R.Q.; Zhang, R.M.; Wang, S.F.; Sun, G.; Xie, H.Q.; Yu, Y.; et al. Association of Ang-2, vWF, and EVLWI with risk of mortality in sepsis patients with concomitant ARDS: A retrospective study. J. Formos. Med. Assoc. 2020, 119, 950-956. [CrossRef]

41. Mellado-Artigas, R.; Mujica, L.E.; Ruiz, M.L.; Ferreyro, B.L.; Angriman, F.; Arruti, E.; Torres, A.; Barbeta, E.; Villar, J.; Ferrando, C. Predictors of failure with high-flow nasal oxygen therapy in COVID-19 patients with acute respiratory failure: A multicenter observational study. J. Intensive Care 2021, 9, 23. [CrossRef]

42. Garner, O.; Dongarwar, D.; Salihu, H.M.; Perez, J.H.B.; Abraham, J.; McBride, C.; Mathew, S.; Anthony, P.; Collins, K.; Richards, K.L.; et al. Predictors of failure of high flow nasal cannula failure in acute hypoxemic respiratory failure due to COVID-19. Respir. Med. 2021, 185, 106474. [CrossRef]

43. Ageno, W.; Cogliati, C.; Perego, M.; Girelli, D.; Crisafulli, E.; Pizzolo, F.; Olivieri, O.; Cattaneo, M.; Benetti, A.; Corradini, E.; et al. Clinical risk scores for the early prediction of severe outcomes in patients hospitalized for COVID-19. Intern. Emerg. Med. 2021, 16, 989-996. [CrossRef]

44. Wang, Q.; Cheng, J.; Shang, J.; Wang, Y.; Wan, J.; Yan, Y.-q.; Liu, W.-B.; Zhang, H.-P.; Wang, J.-p.; Wang, X.-y.; et al. Clinical value of laboratory indicators for predicting disease progression and death in patients with COVID-19: A retrospective cohort study. BMJ Open 2021, 11, e043790. [CrossRef] [PubMed]

45. Uzundere, O.; Kaçar, C.K.; Akelma, H.; Gül, M.S.; Kandemir, D.; Akol, Ü.; Yektaş, A. Indicators that determine disease course in COVID-19 patients. Ulus Travma Acil Cerrahi Derg. 2021, 27, 668-676. [CrossRef] [PubMed]

46. Lokwani, D.P.; Yadav, B.S.; Bharti, S.; Gupta, V.; Toppo, N. Evaluation of hematological, coagulation and inflammatory biomarker's role in predicting the severity of disease in patients with COVID-19, admitted in designated COVID-19 hospital of central India. Indian J. Pathol. Microbiol. 2021, 64, 735-740. [PubMed]

47. Deng, F.; Zhang, L.; Lyu, L.; Lu, Z.; Gao, D.; Ma, X.; Guo, Y.; Wang, R.; Gong, S.; Jiang, W. Increased levels of ferritin on admission predicts intensive care unit mortality in patients with COVID-19. Med. Clin. 2021, 156, 324-331. [CrossRef]

48. Sayah, W.; Berkane, I.; Guermache, I.; Sabri, M.; Lakhal, F.Z.; Yasmine Rahali, S.; Djidjeli, A.; Lamara Mahammed, L.; Merah, F.; Belaid, B.; et al. Interleukin-6, procalcitonin and neutrophil-to-lymphocyte ratio: Potential immune-inflammatory parameters to identify severe and fatal forms of COVID-19. Cytokine 2021, 141, 155428. [CrossRef]

49. Santa Cruz, A.; Mendes-Frias, A.; Oliveira, A.I.; Dias, L.; Matos, A.R.; Carvalho, A.; Capela, C.; Pedrosa, J.; Castro, A.G.; Silvestre, R. Interleukin-6 Is a Biomarker for the Development of Fatal Severe Acute Respiratory Syndrome Coronavirus 2 Pneumonia. Front. Immunol. 2021, 12, 613422. [CrossRef]

50. Yeh, L.C.; Huang, P.W.; Hsieh, K.H.; Wang, C.H.; Kao, Y.K.; Lin, T.H.; Lee, X.L. Elevated Plasma Levels of Gas6 Are Associated with Acute Lung Injury in Patients with Severe Sepsis. Tohoku J. Exp. Med. 2017, 243, 187-193. [CrossRef]

51. Agrawal, A.; Zhuo, H.; Brady, S.; Levitt, J.; Steingrub, J.; Siegel, M.D.; Soto, G.; Peterson, M.W.; Chesnutt, M.S.; Matthay, M.A.; et al. Pathogenetic and predictive value of biomarkers in patients with ALI and lower severity of illness: Results from two clinical trials. Am. J. Physiol. Lung Cell. Mol. Physiol. 2012, 303, L634-L639. [CrossRef]

52. McClintock, D.; Zhuo, H.; Wickersham, N.; Matthay, M.A.; Lorraine, B.W. Biomarkers of inflammation, coagulation and fibrinolysis predict mortality in acute lung injury. Crit. Care 2008, 12, R41. [CrossRef]

53. Jensen, J.U.; Lundgren, B.; Hein, L.; Mohr, T.; Petersen, P.L.; Andersen, L.H.; Lauritsen, A.O.; Hougaard, S.; Mantoni, T.; Bømler, B.; et al. The Procalcitonin And Survival Study (PASS)—A randomised multi-center investigator-initiated trial to investigate whether daily measurements biomarker Procalcitonin and pro-active diagnostic and therapeutic responses to abnormal Procalcitonin levels, can improve survival in intensive care unit patients. Calculated sample size (target population): 1000 patients. BMC Infect. Dis. 2008, 8, 91.

54. Alhazzani, W.; Møller, M.H.; Arabi, Y.M.; Loeb, M.; Gong, M.N.; Fan, E.; Oczkowski, S.; Levy, M.M.; Derde, L.; Dzierba, A.; et al. Surviving Sepsis Campaign: Guidelines on the management of critically ill adults with Coronavirus Disease 2019 (COVID-19). Intensive Care Med. 2020, 46, 854-887. [CrossRef]

55. Coppadoro, A.; Benini, A.; Fruscio, R.; Verga, L.; Mazzola, P.; Bellelli, G.; Carbone, M.; Mulinacci, G.; Soria, A.; Noè, B.; et al. Helmet CPAP to treat hypoxic pneumonia outside the ICU: An observational study during the COVID-19 outbreak. Crit. Care 2021, 25, 80. [CrossRef]

56. Perkins, G.D.; Ji, C.; Connolly, B.A.; Couper, K.; Lall, R.; Baillie, J.K.; Bradley, J.M.; Dark, P.; Dave, C. An adaptive randomized controlled trial of non-invasive respiratory strategies in acute respiratory failure patients with COVID-19. MedRxiv 2021. [CrossRef] 
57. Aliberti, S.; Aliberti, S.; Radovanovic, D.; Billi, F.; Sotgiu, G.; Costanzo, M.; Pilocane, T.; Saderi, L.; Gramegna, A.; Rovellini, A.; et al. Helmet CPAP treatment in patients with COVID-19 pneumonia: A multicentre cohort study. Eur. Respir. J. 2020, 56, 2001935. [CrossRef]

58. Walker, J.; Dolly, S.; Ng, L.; Prior-Ong, M.; Sabapathy, K. The role of CPAP as a potential bridge to invasive ventilation and as a ceiling-of-care for patients hospitalized with COVID-19-An observational study. PLoS ONE 2020, 15, e0244857. [CrossRef]

59. Nightingale, R.; Nwosu, N.; Kutubudin, F.; Fletcher, T.; Lewis, J.; Frost, F.; Haigh, K.; Robinson, R.; Kumar, A.; Jones, G.; et al. Is continuous positive airway pressure (CPAP) a new standard of care for type 1 respiratory failure in COVID-19 patients? A retrospective observational study of a dedicated COVID-19 CPAP service. BMJ Open Respir. Res. 2020, 7, e000639. [CrossRef]

60. Ramirez, G.A.; Bozzolo, E.P.; Castelli, E.; Marinosci, A.; Angelillo, P.; Damanti, S.; Scotti, R.; Gobbi, A.; Centurioni, C.; Di Scala, F.; et al. Continuous positive airway pressure and pronation outside the intensive care unit in COVID 19 ARDS. Minerva Med. 2020. [CrossRef]

61. Duca, A.; Memaj, I.; Zanardi, F.; Preti, C.; Alesi, A.; Della Bella, L.; Ghezzi, E.; Di Marco, F.; Lorini, F.L.; Venturelli, S. Severity of respiratory failure and outcome of patients needing a ventilatory support in the Emergency Department during Italian novel coronavirus SARS-CoV2 outbreak: Preliminary data on the role of Helmet CPAP and Non-Invasive Positive Pressure Ventilation. EClinicalMedicine 2020, 24, 100419.

62. Radovanovic, D.; Pini, S.; Saad, M.; Perotto, L.; Giulani, F.; Santus, P. Predictors of weaning from helmet CPAP in patients with COVID-19 pneumonia. Crit. Care 2021, 25, 206. [CrossRef]

63. Kofod, L.M.; Nielsen Jeschke, K.; Kristensen, M.T.; Krogh-Madsen, R.; Monefeldt Albek, C.; Hansen, E.F. COVID-19 and acute respiratory failure treated with CPAP. Eur. Clin. Respir. J. 2021, 8, 1910191. [CrossRef]

64. Damanti, S.; Ramirez, G.A.; Bozzolo, E.P.; Rovere-Querini, P.; De Lorenzo, R.; Magnaghi, C.; Scotti, R.; Di Lucca, G.; Marinosci, A.; Strada, S.; et al. 6-Month Respiratory Outcomes and Exercise Capacity of COVID-19 Acute Respiratory Failure Patients Treated With CPAP. Intern. Med. J. 2021. [CrossRef] [PubMed]

65. Mas, A.; Masip, J. Noninvasive ventilation in acute respiratory failure. Int. J. Chron. Obstruct. Pulmon. Dis. 2014, 9, 837-852. [PubMed]

66. Rochwerg, B.; Brochard, L.; Elliot, M.W.; Hess, D.; Hill, N.S.; Nava, S.; Navalesi, P.; Antonelli, M.; Brozek, J.; Conti, G.; et al. Official ERS/ATS clinical practice guidelines: Noninvasive ventilation for acute respiratory failure. Eur. Respir. J. 2017, 50, 1602426. [CrossRef] [PubMed]

67. Martin-Gonzalez, F.; González-Robledo, J.; Sánchez-Hernández, F.; Moreno-García, M.N.; Barreda-Mellado, I. Effectiveness and predictors of failure of noninvasive mechanical ventilation in acute respiratory failure. Med. Intensiva 2016, 40, 9-17. [CrossRef]

68. Braunlich, J.; Kohler, M.; Wirtz, H. Nasal highflow improves ventilation in patients with COPD. Int. J. Chron. Obstruct. Pulmon. Dis. 2016, 11, 1077-1085. [CrossRef]

69. Grieco, D.L.; Menga, L.S.; Cesarano, M.; Rosà, T.; Spadaro, S.; Bitondo, M.M.; Montomoli, J.; Falò, G.; Tonetti, T.; Cutuli, S.L.; et al. Effect of Helmet Noninvasive Ventilation vs High-Flow Nasal Oxygen on Days Free of Respiratory Support in Patients With COVID-19 and Moderate to Severe Hypoxemic Respiratory Failure: The HENIVOT Randomized Clinical Trial. JAMA 2021, 325, 1731-1743. [CrossRef]

70. Bertaina, M.; Nuñez-Gil, I.J.; Franchin, L.; Fernández Rozas, I.; Arroyo-Espliguero, R.; Viana-Llamas, M.C.; Romero, R.; Maroun Eid, C.; Uribarri, A.; Becerra-Muñoz, V.M.; et al. Non-invasive ventilation for SARS-CoV-2 acute respiratory failure: A subanalysis from the HOPE COVID-19 registry. Emerg. Med. J. 2021, 38, 359-365. [CrossRef]

71. Ramirez, G.A.; Bozzolo, E.P.; Gobbi, A.; Castelli, E.; Centurioni, C.; DI Meo, M.; Della Torre, E.; DI Scala, F.; Morgillo, A.; Marinosci, A.; et al. Outcomes of non-invasive ventilation as the ceiling of treatment in patients with COVID-19. Panminerva Med. 2021. [CrossRef]

72. Bastoni, D.; Poggiali, E.; Vercelli, A.; Demichele, E.; Tinelli, V.; Iannicelli, T.; Magnacavallo, A. Prone positioning in patients treated with non-invasive ventilation for COVID-19 pneumonia in an Italian emergency department. Emerg. Med. J. 2020, 37, 565-566. [CrossRef]

73. Burton-Papp, H.C.; Jackson, A.I.R.; Beecham, R.; Ferrari, M.; Nasim, M.M.; Grocott, M.P.W.; Chambers, R.; Dushianthan, A University Hospital Southampton Critical Care Team; REACT COVID Investigators. Conscious prone positioning during non-invasive ventilation in COVID-19 patients: Experience from a single centre. F1000Research 2020, 9, 859. [CrossRef]

74. Radovanovic, D.; Rizzi, M.; Pini, S.; Saad, M.; Chiumello, D.A.; Santus, P. Helmet CPAP to Treat Acute Hypoxemic Respiratory Failure in Patients with COVID-19: A Management Strategy Proposal. J. Clin. Med. 2020, 9, 1191. [CrossRef]

75. Rajdev, K.; Spanel, A.J.; McMillan, S.; Lahan, S.; Boer, B.; Birge, J.; Thi, M. Pulmonary Barotrauma in COVID-19 Patients With ARDS on Invasive and Non-Invasive Positive Pressure Ventilation. J. Intensive Care Med. 2021, 9719. [CrossRef]

76. Frat, J.P.; Thille, A.W.; Mercat, A.; Girault, C.; Ragot, S.; Perbet, S.; Prat, G.; Boulain, T.; Morawiec, E.; Cottereau, A.; et al. High-flow oxygen through nasal cannula in acute hypoxemic respiratory failure. N. Engl. J. Med. 2015, 372, 2185-2196. [CrossRef]

77. Corley, A.; Caruana, L.R.; Barnett, A.G.; Tronstad, O.; Fraser, J.F. Oxygen delivery through high-flow nasal cannulae increase end-expiratory lung volume and reduce respiratory rate in post-cardiac surgical patients. Br. J. Anaesth. 2011, 107, 998-1004. [CrossRef]

78. Oczkowski, S.; Ergan, B.; Bos, L.; Chatwin, M.; Ferrer, M.; Gregoretti, C.; Heunks, L.; Frat, J.P.; Longhini, F.; Nava, S.; et al. ERS Clinical Practice Guidelines: High-flow nasal cannula in acute respiratory failure. Eur. Respir. J. 2021. [CrossRef] 
79. Rochwerg, B.; Granton, D.; Wang, D.X.; Helviz, Y.; Einav, S.; Frat, J.P.; Mekontso-Dessap, A.; Schreiber, A.; Azoulay, E.; Mercat, A.; et al. High flow nasal cannula compared with conventional oxygen therapy for acute hypoxemic respiratory failure: A systematic review and meta-analysis. Intensive Care Med. 2019, 45, 563-572. [CrossRef]

80. Ricard, J.D.; Roca, O.; Lemiale, V.; Corley, A.; Braunlich, J.; Jones, P.; Kang, B.J.; Lellouche, F.; Nava, S.; Rittayamai, N.; et al. Use of nasal high flow oxygen during acute respiratory failure. Intensive Care Med. 2020, 46, 2238-2247. [CrossRef]

81. NICE. The National Institute for Health and Care Excellence. COVID-19 Rapid Guideline: Managing COVID-19. 2021. Available online: https:/ / www.nice.org.uk/guidance/ng191/resources / covid19-rapid-guideline-managing-covid19-pdf-51035553326 (accessed on 12 February 2021).

82. Mellado-Artigas, R.; Ferreyro, B.L.; Angriman, F.; Hernandez-Sanz, M.; Arruti, E.; Torres, A.; Villar, J.; Brochard, L. High-flow nasal oxygen in patients with COVID-19-associated acute respiratory failure. Crit. Care 2021, 25, 58. [CrossRef]

83. Demoule, A.; Vieillard, B.A.; Darmon, M.; Beurton, A.; Géri, G.; Voiriot, G.; Dupont, T.; Zafrani, L.; Girodias, L.; Labbé, V.; et al. High-Flow Nasal Cannula in Critically III Patients with Severe COVID-19. Am. J. Respir. Crit. Care Med. 2020, 202, $1039-1042$. [CrossRef]

84. Patel, M.; Gangemi, A.; Marron, R.; Chowdhury, J.; Yousef, I.; Zheng, M.; Mills, N.; Tragesser, L.; Giurintano, J.; Gupta, R.; et al. Retrospective analysis of high flow nasal therapy in COVID-19-related moderate-to-severe hypoxaemic respiratory failure. BMJ Open Respir. Res. 2020, 7, e000650. [CrossRef]

85. Wang, K.; Zhao, W.; Li, J.; Shu, W.; Duan, J. The experience of high-flow nasal cannula in hospitalized patients with 2019 novel coronavirus-infected pneumonia in two hospitals of Chongqing, China. Ann. Intensive Care 2020, 10, 37. [CrossRef] [PubMed]

86. Jayakumar, D.; Ramachandran, D.P.; Rabindrarajan, D.E.; Vijayaraghavan Md, B.; Ramakrishnan Ab, N.; Venkataraman, A.R. Standard Care Versus Awake Prone Position in Adult Nonintubated Patients With Acute Hypoxemic Respiratory Failure Secondary to COVID-19 Infection-A Multicenter Feasibility Randomized Controlled Trial. J. Intensive Care Med. 2021, 36, 918-924. [CrossRef] [PubMed]

87. Taylor, S.P.; Bundy, H.; Smith, W.M.; Skavroneck, S.; Taylor, B.; Kowalkowski, M. Awake Prone Positioning Strategy for Nonintubated Hypoxic Patients with COVID-19: A Pilot Trial with Embedded Implementation Evaluation. Ann. Am. Thorac. Soc. 2021, 18, 1360-1368. [CrossRef]

88. Cammarota, G.; Rossi, E.; Vitali, L.; Simonte, R.; Sannipoli, T.; Anniciello, F.; Vetrugno, E.; Bignami, E.; Becattini, C.; Tesoro, S.; et al. Effect of awake prone position on diaphragmatic thickening fraction in patients assisted by noninvasive ventilation for hypoxemic acute respiratory failure related to novel coronavirus disease. Crit. Care 2021, 25, 305. [CrossRef] [PubMed]

89. Mukhtar, A.; Lotfy, A.; Hasanin, A.; El-Hefnawy, I.; El Adawy, A. Outcome of non-invasive ventilation in COVID-19 critically ill patients: A Retrospective observational Study. Anaesth. Crit. Care Pain Med. 2020, 39, 579-580. [CrossRef] 